\title{
Detecting Channel Riparian Vegetation Response to Best-Management-Practices Implementation in Ephemeral Streams With the Use of Spot High-Resolution Visible Imagery
}

\author{
Kendall Vande Kamp, ${ }^{1}$ Matthew Rigge, ${ }^{2}$ Nels H. Troelstrup, Jr., ${ }^{3}$ Alexander J. Smart, ${ }^{3}$ \\ and Bruce Wylie
}

\begin{abstract}
Authors are ${ }^{1}$ Graduate Research Assistant and ${ }^{3}$ Professor, Department of Natural Resource Management, South Dakota State University, Brookings, SD 57007, USA; ${ }^{2}$ Range Ecologist, Arctic Slope Regional Corporation Research \& Technology Solutions, Contractor to US Geological Survey Earth Resources Observation and Science Center, Sioux Falls, SD 57198, USA; and ${ }^{4}$ Research Physical Scientist, US Geological Survey Earth Resources Observation and Science Center, Sioux Falls, SD 57198, USA.
\end{abstract}

\begin{abstract}
Heavily grazed riparian areas are commonly subject to channel incision, a lower water table, and reduced vegetation, resulting in sediment delivery above normal regimes. Riparian and in-channel vegetation functions as a roughness element and dissipates flow energy, maintaining stable channel geometry. Ash Creek, a tributary of the Bad River in western South Dakota contains a high proportion of incised channels, remnants of historically high grazing pressure. Best management practices (BMP), including off-stream watering sources and cross fencing, were implemented throughout the Bad River watershed during an Environmental Protection Agency (EPA) 319 effort to address high sediment loads. We monitored prairie cordgrass (Spartina pectinata Link) establishment within stream channels for $16 \mathrm{yr}$ following BMP implementation. Photos were used to group stream reaches $(n=103)$ subjectively into three classes; absent (estimated $<5 \%$ cover; $n=64)$, present (estimated $5-40 \%$ cover; $n=23)$, and dense (estimated $>40 \%$ cover; $n=16$ ) based on the relative amount of prairie cordgrass during 2010 assessments of ephemeral channels. Reaches containing drainage areas of 0.54 to 692 ha were delineated with the use of 2010 National Agriculture Imagery Program (NAIP) imagery. Normalized difference vegetation index (NDVI) values were extracted from 5 to 39 sample points proportional to reach length using a series of Satellite Pour l'Observation de la Terre (SPOT) satellite imagery. Normalized NDVI (nNDVI) of 2152 sample points were determined from pre- and post-BMP images. Mean nNDVI values for each reach ranged from 0.33 to 1.77 . ANOVA revealed significant increase in nNDVI in locations classified as present prairie cordgrass cover following BMP implementation. Establishment of prairie cordgrass following BMP implementation was successfully detected remotely. Riparian vegetation such as prairie cordgrass adds channel roughness that reduces the flow energy responsible for channel degradation.
\end{abstract}

Key Words: channel morphology, Conservation Effects Assessment Project (CEAP), northern mixed-grass prairie, prairie cordgrass, remote sensing

\section{INTRODUCTION}

Cattle in rangelands spend a disproportionate amount of time in riparian zones because of the abundance of forage, water, and shade (Bailey 2005). Riparian areas are vulnerable to overuse because of the draw of cattle combined with their relatively small extent (Fleischner 1994). Eliminating direct cattle access to streams by fencing is most effective when attempting to restore riparian health and function (Elmore and Kauffman 1994). However, fencing out entire stream reaches within a pasture is not always practical or desirable to cattle producers. Best management practices (BMP) that reduce the probability of access and/or time spent in riparian zones, such

Research was funded by the USDA Conservation Effects Assessment Project (CEAP) 2009-51130-06014 and USGS Climate and Land Use Program Research and Development GX11ED00BJHZHO0.

Correspondence: Nels. H. Troelstrup, Jr., Dept of Natural Resource Management, South Dakota State University, Brookings, SD 57007, USA. Email: nels.troelstrup@sdstate. edu

Manuscript received 20 August 2011; manuscript accepted 12 July 2012.

(c) 2013 The Society for Range Management as alternative water sources, rock crossings, and specialized grazing systems, have been moderately effective at improving riparian vegetation, physical and chemical properties of streams, and abundance of aquatic life forms (Elmore and Kauffman 1994; Agouridis et al. 2005; DelCurto et al. 2005). Off-stream water sources, such as piped water into cattle drinking troughs and strategic mineral placement are attractive management alternatives for producers because they increase grazing distribution and can increase animal rate of weight gain (Porath et al. 2002). For these reasons, range improvement practices such as cross fencing, water pipelines, and off-stream water sources have often been cost shared by the USDA-NRCS (George et al. 2011) and readily adopted by producers.

The impacts of cattle on stream channel degradation are difficult to distinguish because of multiple factors contributing to the structure and function of stream channels, including gradient, geology, climate, upland and riparian plant communities, and land-use practices (Allen 1995). Fluvial processes are regulated by climate, physiography, and vegetation, and are continually adjusting to changes of these components (Montegomery and Bolton 2003). Of the factors influencing fluvial processes, vegetation is most easily influenced by land 
management. Sandercock et al. (2007) identified two components of riparian vegetation that influence channel processes: 1) vegetation roughness that helps to dissipate flow energy, and 2) roots that help to stabilize bed and bank features. Manning's (1891) equation is the most widely used equation for evaluating resistance components within open channels:

$$
V=1 / n \cdot R^{2 / 3} \cdot S^{1 / 2},
$$

where $V=$ average flow velocity, $R$ =hydraulic radius, $S=$ average gradient, and Manning's roughness coefficient $(n)$ is the sum of the components that affect the roughness of the channel. Components of roughness $(n)$ were classified by Cowan (1956) (Eq. 2):

$$
n_{\mathrm{tot}}=\left(n_{b}+n_{1}+n_{2}+n_{3}+n_{4}\right) m,
$$

where $n_{\text {tot }}$ is the total roughness, $n_{\mathrm{b}}$ is the base $n$ for a straight uniform channel, $n_{1}$ is a correction factor for irregularities, $n_{2}$ is a value for variations in cross-section shape and size, $n_{3}$ a value for obstructions, $n_{4}$ a value for vegetation (density, flexibility, and height relative to flow depth), and $m$ factors in channel meandering. Vegetation is an important contributor to channel roughness, as it has demonstrated to have greater influence than other roughness components (Table 1 ). The $n_{4}$ value will be greater when depth of flow is shallow relative to the size of roughness components. For example, when channel vegetation is sparse, flexible, and short relative to depth of flow $(<2 \times$ water depth), little resistance is provided. Conversely, dense vegetation with sturdy and tall stems relative to flow depth ( $>2 \times$ water depth) would provide substantial resistance (Cowan 1956). Flow depths are generally shallow in ephemeral systems, increasing the weight of vegetation as a roughness component (Sandercock et al. 2007). In-channel vegetation is especially important in reducing flow energy during floods ( $\mathrm{Li}$ and Shen 1973) when sediment transport is at its peak. Sediment transport in first-order ephemeral channels is intimately related to the stochastic nature of short-pulsed, high-amplitude flow events. Therefore, increasing the length of the pulse and decreasing the amplitude of runoff by increasing surface roughness is critical to easing sediment transport.

Prairie cordgrass (Spartina pectinata Link), is a native perennial warm-season grass that grows throughout much of North America. It typically is found in poorly drained soils, but is also well adapted to seasonally dry sites (Stubbendieck et al. 1992). It functions as a stream-channel stabilizer and traps sediment (Weaver 1960; Johnson and Larson 1999; Boe and Lee 2007). Once established, stands of prairie cordgrass are highly resistant to hydrological regimes, promote deposition, add riparian habitat diversity, and produce significant quantities of plant biomass (Skinner et al. 2009). Prairie cordgrass has rough leaf blade edges that result in low palatability, and therefore is avoided by cattle except when in an early vegetative growth stage. Sedgwick and Knopf (1991) reported increased prairie cordgrass biomass in response to prescribed grazing over a 3-yr period. For these reasons, prairie cordgrass is an ideal plant for revegetating incised ephemeral stream channels because of its resilience under grazing pressure and harsh hydrologic regimes.

In western South Dakota, the mixed-grass prairie upland vegetation is predominantly a mix of cool-season midgrasses and an understory of warm-season shortgrasses (Smart et al.
Table 1. Computation sheet for Manning's roughness coefficient, after

\begin{tabular}{|c|c|c|}
\hline Variable & Description & $n$ value \\
\hline \multirow[t]{4}{*}{ Basic, $n_{b}{ }^{1}$} & Earth & 0.020 \\
\hline & Rock & 0.025 \\
\hline & Fine gravel & 0.024 \\
\hline & Coarse gravel & 0.028 \\
\hline \multirow[t]{4}{*}{ Irregularity, $n_{1}$} & Smooth & 0.000 \\
\hline & Minor & 0.005 \\
\hline & Moderate & 0.010 \\
\hline & Severe & 0.020 \\
\hline \multirow[t]{3}{*}{ Cross section, $n_{2}$} & Gradual & 0.000 \\
\hline & Occasional & 0.005 \\
\hline & Alternating & $0.010-0.015$ \\
\hline \multirow[t]{4}{*}{ Obstructions, $n_{3}{ }^{1}$} & Negligible & 0.000 \\
\hline & Minor & $0.010-0.015$ \\
\hline & Appreciable & $0.020-0.030$ \\
\hline & Severe & $0.040-0.060$ \\
\hline \multirow[t]{4}{*}{ Vegetation, $n_{4}$} & Low & $0.005-0.010$ \\
\hline & Medium & $0.010-0.020$ \\
\hline & High & $0.025-0.050$ \\
\hline & Very high & $0.050-0.100$ \\
\hline \multirow[t]{3}{*}{ Meandering, $m$} & Minor & 0.000 \\
\hline & Appreciable & $0.15 n_{s}^{2}$ \\
\hline & Severe & $0.30 n_{s}^{2}$ \\
\hline
\end{tabular}
Cowan (1956).

${ }^{1}$ No variation in these variables were found in Ash Creek.

${ }^{2} n_{s}=n_{b}+n_{1}+n_{2}+n_{3}+n_{4}$.

2007). Upland vegetation in western South Dakota, dominated by the cool-season species western wheatgrass (Pascopyrum smithii [Rybd.]), largely senesces by the end of June (White 1983). Distinct phenologic differences between upland and riparian species in western South Dakota provide the opportunity for remote detection of in-channel vegetation signal within narrow riparian areas in late summer with little influence from adjacent senesced cool-season-dominated upland vegetation.

Remote sensing techniques including the normalized difference vegetation index (NDVI) have demonstrated strong correlations with aboveground plant biomass (Wylie et al. 2002; Al-Bakri and Taylor 2003; Kawamura et al. 2005). However, remote sensing studies have tended to avoid riparian areas because of their inherent complexity. Diverse mixtures of vegetation types in addition to the presence of bare ground and boundary pixels often degrades the ability of the NDVI to measure actively photosynthesizing biomass (Nagler et al. 2001). The riparian remote sensing literature has given little attention to herbaceous riparian areas (Lyons et al. 2000), specifically the semiarid Great Plains.

High-resolution satellite imagery such as Satellite Pour l'Observation de la Terre (SPOT) high-resolution visible (HRV) and Landsat have been used successfully in riparian areas. Svoray (2004), for example, characterized stream channelization remotely with the use of SPOT imagery. Lattin et al. (2004) successfully assessed land cover/land use and biotic integrity of Oregon riparian areas with both aerial photography and Landsat imagery, noting that the increased spectral resolution and multiple image dates possible with satellite 
imagery offer distinct advantages in accurately classifying vegetation compared to higher-resolution aerial photography.

Determining the effects of BMP implementation requires both baseline and postimplementation monitoring, allowing an appropriate time period for BMP-induced response. The value of remote sensing is amplified when necessary baseline data are not collected for the metric being used to measure improvement, a common issue when evaluating BMP effectiveness. Remote sensing provides a means to mitigate this issue, granted imagery of sufficient resolution is available from necessary periods. Though the influence of land management on vegetation production is often masked by interannual weather variations, long-term monitoring of vegetative productivity is essential in evaluating the suitability of land management and success of BMP practices (Gu and Wylie 2010).

The objective of this study was to evaluate the collective influence of BMPs (including off-stream water sources and improved grazing management) on riparian prairie cordgrass communities by utilizing SPOT HRV imagery pre- and postBMP implementation in a western South Dakota watershed. Our results can be used to assess the ecological impacts of riparian management practices better (George et al. 2011). We hypothesized that prairie cordgrass cover increased following BMP implementation and can be monitored remotely with the use of a time series of SPOT HRV imagery.

\section{METHODS}

Ash Creek lies within the lower Bad River basin in west central South Dakota (Fig. 1). Topography is characterized by steep slopes of $16-45 \%$, stabilized by fragile rangeland vegetation. Lack of glaciation throughout the study area has resulted in a well-defined drainage pattern that is quite apparent, as the Bad River has cut a 40-80-m-deep valley into the landscape. Gullies are often found in the breaks formation, the transition from tablelands to valley bottom of the Bad River and its tributaries. The geology of the region is dominated by Pierre shale (including Sansarc-Pierre and Sansarc-Opal), which reaches a depth of over $300 \mathrm{~m}$. These cretaceous deposits are widely exposed in eroding banks and gullies, especially in the lower basin, and have a high clay content, making them relatively impermeable.

The Bad River basin has a continental climate, with daily mean temperatures ranging from $32^{\circ} \mathrm{C}$ in July to $-14^{\circ} \mathrm{C}$ in January, with a yearly mean of $8^{\circ} \mathrm{C}$ (Smart et al. 2007). Growing season (frost-free days) averages 115-130 d. The semiarid landscape of the Bad River watershed receives 380$410 \mathrm{~mm}$ of precipitation annually, of which $80 \%$ occurs during the April to September growing season. Between 1971 and 2010, 80\% of annual runoff occurred during a 4-mo period from March through June (USGS station 06441500). Predominant land uses within the watershed are rangeland $\approx 75 \%$ and dryland agriculture $\approx 25 \%$.

Rangeland management within Ash Creek underwent significant changes as a result of a larger effort to reduce nonpoint source pollution within the Bad River watershed. The rangeland (3 $372 \mathrm{ha}$ ) was grazed continuously season-long until 1997. In 1997 construction of a cross fence divided a continuous tract of 2580 ha in two separate tracks; water

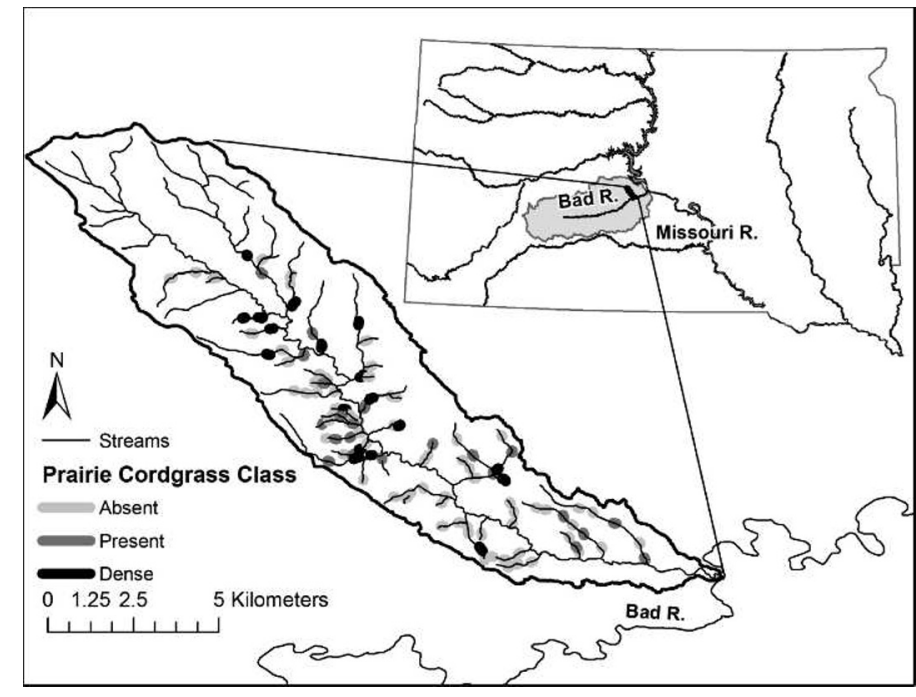

Figure 1. Ash Creek is a subwatershed within the Lower Bad River Basin located in west-central South Dakota. The 2010 ground assessment status of prairie cordgrass class is depicted in the legend.

was pumped from three water lines and several wells into 21 off-stream watering tanks, and rotational grazing was implemented. In 2002, land ownership changed and bison (Bison bison) replaced cattle on the majority of rangelands (2 $580 \mathrm{ha})$. Cattle remained in rotational grazing systems on 703 ha and continuous grazing on 89 ha.

\section{Ground Assessment}

Channel morphology baseline assessment was conducted in 1994 within the Ash Creek watershed prior to BMP implementation. During post-BMP assessment of channel morphology in 2010, presence/absence of prairie cordgrass was recorded. Photos were later used to group sites $(n=103)$ subjectively into three distinct classes; absent $(n=64)$, present $(n=23)$, and dense $(n=16)$ based on the relative amount of prairie cordgrass present (Figs. 2a-2c). Sites classified as absent had no functional (i.e., $<5 \%$ ) prairie cordgrass cover, present sites had scattered prairie cordgrass patches (estimated $5-40 \%$ cover), whereas dense sites had near full coverage of prairie cordgrass (estimated $>40 \%$ cover) with scattered patches of bare ground.

\section{Remote Assessment}

Stream reaches (1:24000 scale, first and second order) containing a range of drainage areas (0.54-692 ha) were delineated with the use of 2010 National Agriculture Inventory Program (NAIP) imagery with the ArcMap 2010 editor. Delineation vertices ( $n=5-39$ per stream reach) were sample locations subsequently used to extract NDVI values from a series of Satellite Pour l'Observation de la Terre (SPOT) highresolution visible (HRV) satellite imagery (Fig. 3). Longer reaches contained more delineation vertices. Images from the SPOT 2, 3, 4, and 5 sensors were used. Imagery from SPOT 5 had an initial resolution of $10 \mathrm{~m}$, which was resampled to $20 \mathrm{~m}$ with the use of the nearest-neighbor method to match the resolution of the other SPOT sensors. NDVI values were extracted from pre-BMP 1987 (30 June and 26 July), 1997 (16 


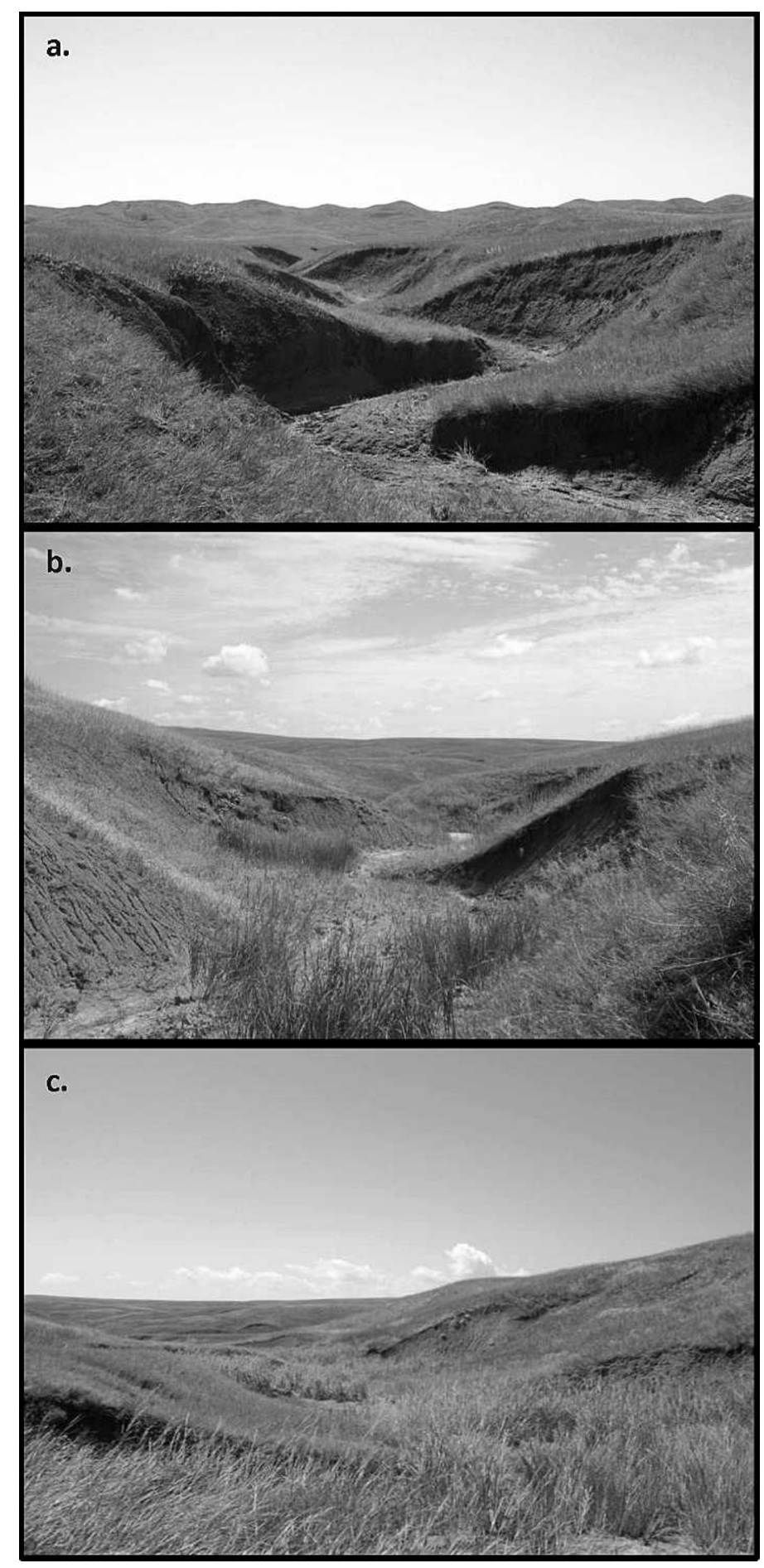

Figure 2. Variation in prairie cordgrass establishment throughout the Ash Creek watershed in western South Dakota. The range of prairie cordgrass site abundance is represented from absent (a), present (b), and dense (c).

July, 26 July, and 27 August), and post-BMP 2010 (26 May, 16 July, and 11 August) images (CCNES, Distribution Spot Image). The 11 August 2010 SPOT HRV scene was selected as a reference to which all other images were standardized. Standardizing was necessary because multitemporal images were acquired by different sensors under variable atmospheric conditions, solar illumination, and view angles (El Hajj et al. 2008). The standardized values of each sample location

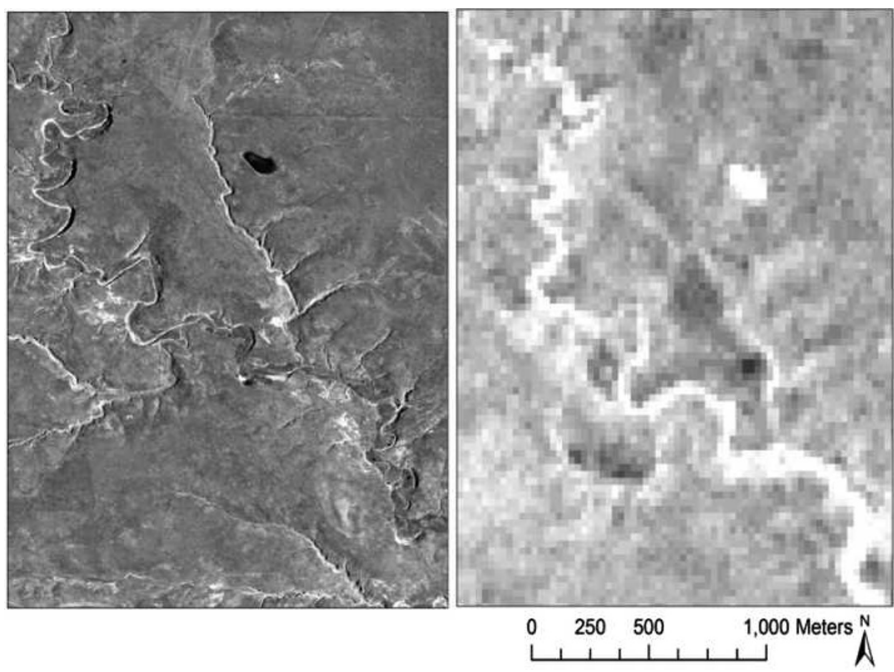

Figure 3. Aerial imagery (left) with 1-m resolution and NDVI generated from Satellite Pour l'Observation de la Terre (SPOT) satellite imagery (right) with 20-m resolution for the same ephemeral stream channels seen above. White areas on the SPOT imagery refer to areas of high vegetation signal, occurring mostly in riparian areas.

$(n=1689)$ were then normalized by dividing each value by the mean standardized NDVI for each respective year so that a normalized NDVI value $<1$ indicates below-average NDVI, whereas a value $>1$ indicates NDVI above the mean. Hereafter, normalized NDVI values will be referred to as nNDVI. Normalization of SPOT imagery has previously been used to reduce variation in nonsurface factors in order to detect actual change in surface conditions (Eckhardt et al. 1990). The influence of interannual differences in precipitation on vegetation productivity can be factored out with the use of normalization, because normalized NDVI values represent a proportion of an image mean. Deterministic and empirical approaches of normalization described by Eckhardt et al. (1990) should be considered in larger-scale projects because of $50 \%$ differences in view angle between east- and west-looking SPOT HRV acquisitions (Moran et al. 1990). Because of the small area studied in this project, a simpler method of normalization is suitable.

\section{Statistical Analysis}

Analysis of variance was used to test the hypotheses that mean nNDVI differed among riparian classes (absent/present/dense) for each individual year $(P=0.05)$. Temporal changes of nNDVI were observed both within a year (2010) to determine if and when differences in nNDVI could be expected to occur among riparian classes, and interannually to determine if patterns indicated change in riparian vegetation classes $(P=0.05)$.

\section{RESULTS}

Significant differences in nNDVI were observed through the duration of the growing season as indicated by the multitemporal 2010 imagery set (Fig. 4). As one would expect, nNDVI increased as a function of vegetation cover. The 


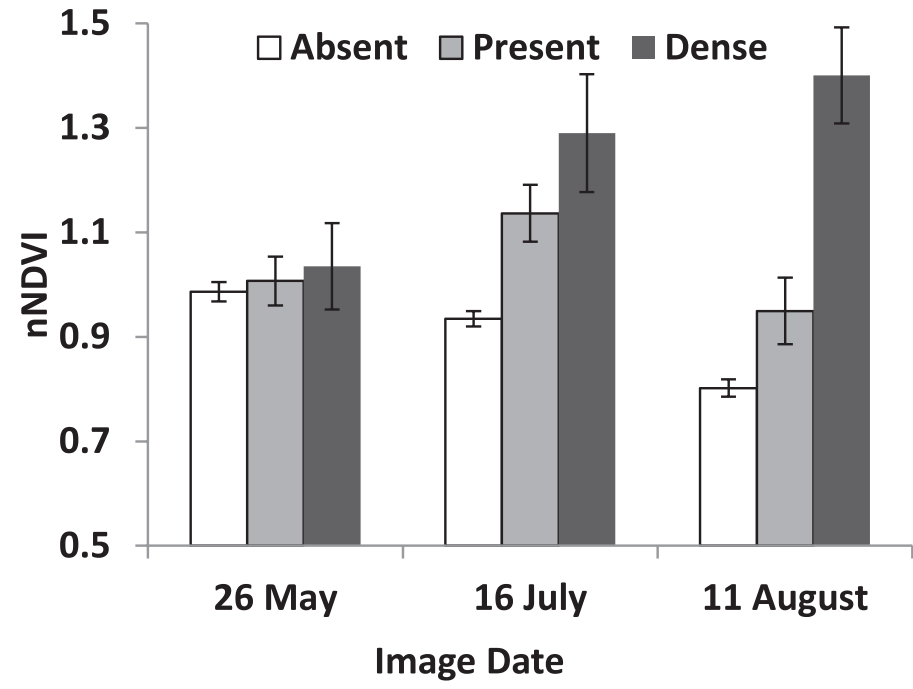

Figure 4. Mean normalized NDVI (nNDVI) and 95\% confidence intervals for sites classified as absent, present, or dense cover of prairie cordgrass cover over a portion of the 2010 growing season.

influence of upland species, both adjacent to and commonly within the channel itself, such as western wheatgrass and Canada wildrye (Elymus canadensis L.), was greatest on absent sites. Present and dense sites were influenced by moderate and heavy prairie cordgrass cover, respectively, with less influence from upland species. The nNDVI signatures of the three cover classes were relatively similar early in the growing season (May); however, as the growing season progressed, upland species senesced while riparian vegetation generally either maintained or gained photosynthesizing biomass. This phenomenon was evident later in the growing season (July and August) when distinct differences in nNDVI became apparent (Fig. 4). Contrast among classes increased in late summer because of the presence of prairie cordgrass, a $\mathrm{C}_{4}$ species, coupled with senescence of $\mathrm{C}_{3}$ upland vegetation. Hence, locations where upland species had proportionately large influence on nNDVI (absent sites) underwent sharp decreases in $\mathrm{nNDVI}$ as the growing season progressed, whereas the nNDVI increased in locations containing prairie cordgrass. This result suggested that imagery early in the growing season was unable to resolve the differences among cover classes. May images were thus excluded from further analysis.

No change in the pattern of nNDVI among the riparian classes was apparent between 1987 and 1997 (Fig. 5). During both time periods dense sites had the highest nNDVI, followed by absent and present sites $(P=0.05)$. Following BMP implementation, present sample pixels $(n=389)$ surpassed absent sample pixels $(n=993)$ in nNDVI in 2010, and for the first time attained an $\mathrm{nNDVI}$ over 1 indicating prairie cordgrass likely established during this period. Samples $(n=307)$ classified as dense prairie cordgrass stands in 2010 had a significantly greater mean nNDVI than absent and present sites in all years $(P=0.01)$ suggesting dense prairie cordgrass stands existed preBMP (1987). Locations classified as present, however, were the only group that displayed a large increase in mean nNDVI (Fig. $5)$.

The mean nNDVI of present sites increased $19.6 \%$ following BMP implementation (Fig. 6). Dense sites maintained similar

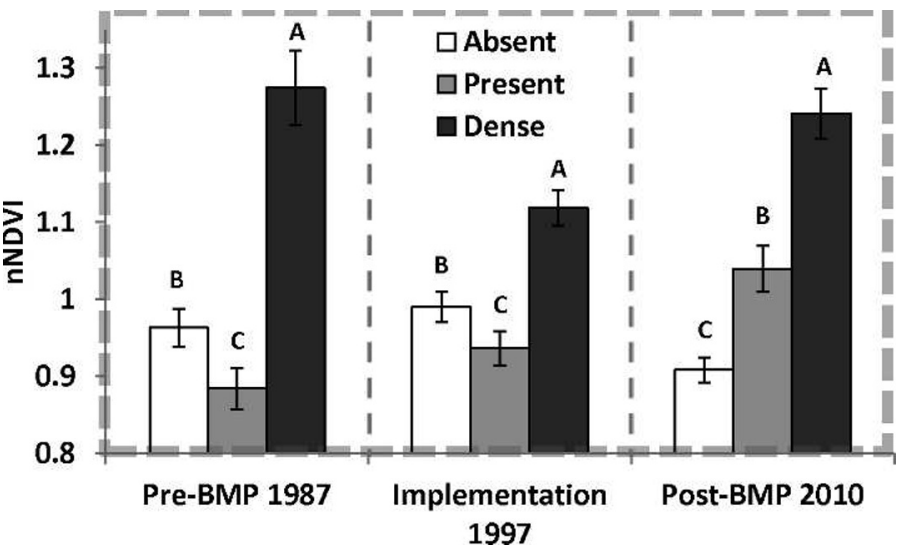

Figure 5. Normalized NDVI (nNDVI) means and 95\% confidence intervals of treatments by year. Letters indicate groups significant at 0.01 Tukey's. The dotted lines represent that each year was statistically analyzed independent from the others.

nNDVI from 1987 to 2010 with a $0.9 \%$ increase, whereas absent sites decreased by $9.6 \%$ (Fig. 6). Between 1987 and 1997 present sites and dense sites displayed contrasting changes. However, the change of present and dense sites from 1997 to 2010 was similar, suggesting establishment of prairie cordgrass in present sites occurred during the post-BMP period (1997-2010).

\section{DISCUSSION}

We determined that prairie cordgrass cover increased within the riparian areas of Ash Creek following BMP implementation, and that the 20-m spatial resolution of SPOT imagery was sufficient to assess BMP impacts, despite riparian areas generally being less than $20 \mathrm{~m}$ in width. The shift in pattern between absent and present sites from 1997 to 2010 provided evidence that prairie cordgrass stands established on locations classified as present $(2.56 \mathrm{~km}=27.5 \%$ of total assessed channel length) following BMP implementation (Fig. 5). The increased average nNDVI in present sites from 1987 to 2010 corresponded with a $27.5 \%$ increase in prairie cordgrass extent (Fig. 6). Prairie cordgrass cover within locations classified as dense in $2010(1.99 \mathrm{~km})$ was presumably established prior to BMP implementation because of having a significantly greater mean nNDVI than absent and present sites in 1987.

Phenological differences between cool-season-dominated upland vegetation and warm-season prairie cordgrass were instrumental in successful characterization of riparian vegetation (Fig. 4). Dry years promoted greater contrast between riparian areas and surrounding upland vegetation, because prairie cordgrass tended to remain photosynthetically active in riparian areas while upland vegetation was largely senesced. Similar findings were reported by Clary and Webster (1989), who found a greater similarity in vegetation vigor between riparian and upland areas in spring than in summer. In 1987, only $75 \%$ of the 1964-2008 mean growing season (AprilSeptember) precipitation occurred, resulting in greater difference in the upland and riparian vegetation signal. Growingseason precipitation was $140 \%$ of the long-term average in 


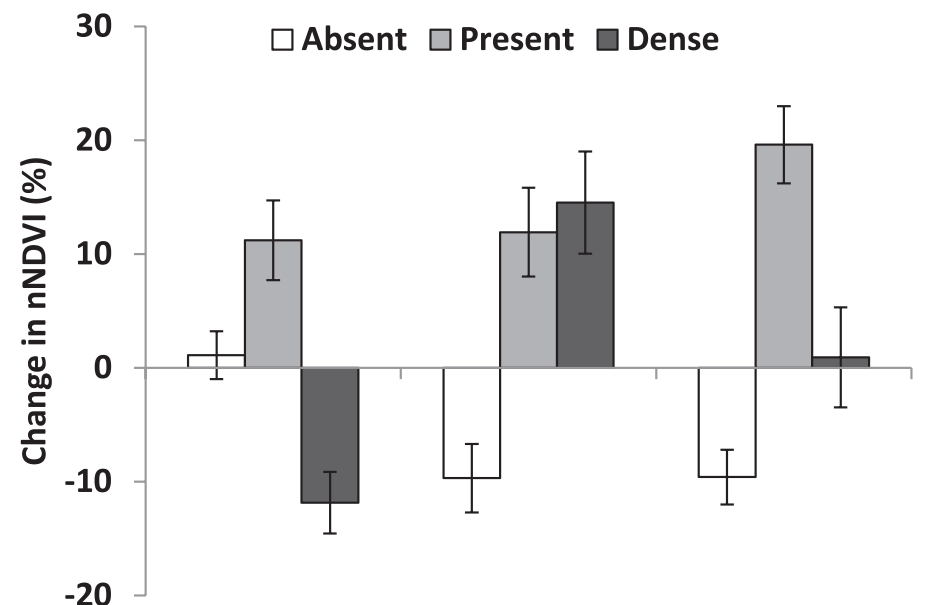

1987-1997

1997-2010

1987-2010

Figure 6. Average percent change in normalized NDVI (nNDVI) from 1987 to 1997 represents pre-best management practice (BMP) change and 1997 to 2010 represents post (BMP) change within prairie cordgrass cover classes. Error bars are $+/-1$ standard error. $\Sigma \Delta \mathrm{nNDVI}=0$.

1997, yielding more homogeneous vegetation across the landscape. In 2010, $138 \%$ of the long-term average growing season precipitation occurred. If less precipitation had occurred in 2010, greater contrasts among riparian classes than observed would be expected, as upland vegetation is more responsive to precipitation. Comparable upland vegetation growth would be expected in 1997 and 2010 because of similar growing-season precipitation. Therefore, the difference in the nNDVI of prairie cordgrass classes between these years was likely attributable to differences in prairie cordgrass cover, not precipitation.

Interannual differences in precipitation partly explained changes in nNDVI among riparian classes among years. For example, the difference in nNDVI between absent and dense sites was greater in 1987 compared to 1997 . This was because of above-normal precipitation in 1997 causing the productivity of upland vegetation to be higher than normal during July and August. Had present sites contained prairie cordgrass cover in 1987, a response similar to dense would have been expected during the 1987-1997 period. The responses between these two classes were, however, exactly opposite from each other during the 1987-1997 period, indicating that prairie cordgrass had not been established in present sites. From 1997 to 2010, which were both wet years, similar direction and magnitude of change in nNDVI for dense and present was observed indicating cordgrass establishment had occurred in present locations. Over the 23-yr study period, no significant change in nNDVI occurred in dense sites; significant increases were found in present sites, whereas absent sites decreased significantly (Fig. 5). Because of the nature of nNDVI ( $\Sigma \Delta \mathrm{nNDVI}=0)$, the decrease in $\mathrm{nNDVI}$ in absent sites occurred as a result of the increased nNDVI of present sites. Presumably, the prairie cordgrass cover of dense sites was greater throughout the study period, whereas prairie cordgrass cover on present sites was established following BMP implementation.

Eliminating direct access to streams by cattle is generally the most effective method to restore riparian vegetation and thereby improve ecological health and function. We demon- strated that implementation of BMPs, including alternate water sources and cross fencing that are readily adopted by producers, were successful at increasing the extent of prairie cordgrass even as cattle were not excluded from riparian areas. Prairie cordgrass functioned as a channel roughness component that reduced flow energy, halted channel degradation, and encouraged retention of sediment (Sandercock et al. 2007). For these reasons, the channel morphology of dense sites was characteristically wide and maintained high width/depth ratios because of channel bed aggradation within historically incised channels (Vande Kamp 2012). This study suggests that prairie cordgrass may be a successful tool to address channel degradation, a pervasive issue in rangelands (Elmore and Kauffman 1994).

The switch from cattle to bison grazing in the majority of study-area rangelands confounded the influence of BMPs, as bison and cattle demonstrate different foraging behavior (Plumb and Dodd 1993; Towne et al. 2005). Signs of inchannel vegetation recovery prior to BMP implementation (1997) were absent. Prairie cordgrass expanded its extent following the implementation of off-stream watering and cross fencing in 1997 and the switch to bison grazing in 2002. Decreased grazing pressure on riparian areas would be expected as a result of both the implementation of off-stream water sources (Sheffield et al. 1997; Porath et al. 2002) and the replacement of cattle with bison (Wuerthner 1998). Though the switch to bison grazing likely aided the recovery of in-channel vegetation, the lack of appropriate replication in the study area did not permit the investigation of the influence of bison in the absence of BMPs. Despite this limitation, we report BMPs including off-stream water sources and cross fencing in combination with bison grazing increased the vigor and extent of prairie cordgrass.

We confirm prairie cordgrass as an ideal species for revegetating and stabilizing stream channels due to its tolerance of harsh hydrologic regimes, ability to dissipate flow energy, and low palatability (Weaver 1960; Johnson and Larson 1999; Boe and Lee 2007). Linking improvements in water quality (e.g., decreased sediment load) with increased NDVI could provide further insight into the capacity of in-channel vegetation to improve water quality. The approach used to evaluate riparian vegetation with SPOT or similar highresolution sensor has potential applications in ephemeral, seasonal, and permanent streams across the Great Plains and other grassland systems.

\section{MANAGEMENT IMPLICATIONS}

Implementation of BMPs including off-stream water sources and cross fencing coupled with replacing cattle with bison in the majority of rangeland corresponded with increase prairie cordgrass extent in stream channels despite continued access to riparian areas. Remote sensing studies have tended to avoid riparian areas because of their complex mixture of upland and riparian vegetation and bare ground. However, the differences in phenology between upland and lowland vegetation combined with the high productivity of prairie cordgrass allowed the riparian vegetation signal to dominate the SPOT imagery in the mid to late growing season. Remote sensing was critical in 
describing pretreatment conditions because detailed field data were absent.

We recognize that the ability of a riparian area to function properly is dependent on retaining vegetative structure and composition under the hydrologic regime of the system. Erosional features (e.g., knickpoints and gullies) in rangelands often begin to form before the carrying capacity is reached, leading to high sediment loads, a common water-quality impairment. Incised channels often are remnants from historical overgrazing and take decades, possibly centuries, to heal. Rangeland managers aim to improve grazing distribution by means of BMPs, including strategic water and mineral placement or cross fencing, allowing resource utilization to be more distributed across a landscape. Our study results suggest that implementation of a BMP suite resulted in a net improvement in riparian and channel vegetation condition. We provide a monitoring tool that can be used to detect in-channel vegetation establishment in response to improved management efforts with limited ground-truthing, a costly activity that often is neglected. Increasing awareness of the benefits these BMPs have on rangelands provides added incentive to producers and rangeland managers to increase efforts adopting improved management practices.

\section{ACKNOWLEDGMENTS}

The authors acknowledge the assistance of Alex Brazeal during field work and two anonymous reviewers for their insightful comments.

\section{LITERATURE CITED}

Agouridis, C. T., S. R. Workman, R. C. Warner, and G. D. Jennings. 2005. Livestock grazing management impacts on stream water quality: a review. Journal of the American Water Resources Association 41:591-606.

Al-BAKRI, J. T., AND J. C. TAYLoR. 2003. Application of NOAA AVHRR for monitoring vegetation conditions and biomass in Jordan. Journal of Arid Environments 54:579-593.

ALLEN, J. D. 1995. Stream ecology: structure and function of running waters. London, UK: Chapman \& Hall. $388 \mathrm{p}$.

BAlLEY, D. W. 2005. Identification and creation of optimum habitat conditions for livestock. Rangeland Ecology \& Management 58:109-118.

Boe, A., And D. K. Lee. 2007. Genetic variation for biomass production in prairie cordgrass and switchgrass. Crop Science 47:929-934.

Clary, W. P., and B. F. Webster. 1989. Managing grazing of riparian areas in the Intermountain Region. Ogden, UT, USA: USDA Forest Service Intermountain Research Station. Gen. Tech. Rep. INT-263. 15 p.

Cowan, W. L. 1956. Estimating hydraulic roughness coefficients. Agricultural Engineering 37:473-475.

DelCurto, T., M. Purath, C. T. Parsons, and J. A. Morrison. 2005. Management strategies for sustainable beef cattle grazing on forested rangelands in the Pacific Northwest. Rangeland Ecology \& Management 58:119-127.

ECKHARDT, D. W., J. P. Verdin, AND G. R. LYFord. 1990. Automated update of an irrigated lands GIS using SPOT HRV imagery. Photogrammetric Engineering \& Remote Sensing 56:1515-1522.

El Haju, M., A. Begue, B. Lafrance, O. Hagolle, G. Dedieu, and M. Rumeau. 2008. Relative radiometric normalization and atmospheric correction of a SPOT 5 time series. Sensors 8:2774-2791.

Elmore, W., and B. Kauffman. 1994. Riparian and watershed systems: degradation and restoration. In: M. Vavra, W. A. Laycock, and R. D. Pieper [EDS.]. Ecological implications of livestock herbivory in the west. Denver, CO, USA: Society for Range Management. p. 212-231.
FleISCHNER, T. L. 1994. Ecological costs of livestock grazing in western North America. Conservation Biology 8:629-644.

George, M. R., R. D. Jackson, C. S. Boyd, and K. W. Tate. 2011. A. scientific assessment of the effectiveness of riparian management practices. In: D. D. Briske [ED.]. Conservation benefits of rangeland practices: assessment, recommendations, and knowledge gaps. Washington, DC, USA: USDA-NRCS. p. 213-252.

Gu, Y., AND B. K. WyLIE. 2010. Detecting ecosystem performance anomalies for land management in the Upper Colorado River Basin using satellite observation, climate data, and ecosystem models. Remote Sensing 2:1880-1891.

Johnson, J. R., AND G. E. LaRson. 1999. Grassland plants of South Dakota and the northern Great Plains. Brookings, SD, USA: South Dakota State University, South Dakota Agricultural Experiment Station. B-566. 288 p.

Kamamura, K., T. Akiyama, H. Yokota, M. Tsutsumi, T. Yasuda, 0. Watanabe, and S. Wang. 2005. Comparing MODIS vegetation indices with AVHRR NDVI for monitoring the forage quantity in Inner Mongolia grassland, China. Grassland Science 51:33-40.

Lattin, P. D., P. J. Wigington, JR., T. J. Moser, B. E. Peniston, D. R. Lindeman, and D. R. OEtTER. 2004. Influence of remote sensing imagery source on quantification of riparian land cover/land use. Journal of the American Water Resources Association 40:215-227.

LI, R.-M., AND H. W. SHEN. 1973. Effect of tall vegetation and flow sediment. Journal of Hydraulics Division 99:793-814.

Lyons, J., S. W. TRIMBLE, AND L. K. PAINE. 2000. Grass versus trees: managing riparian areas to benefits streams of central North America. Journal of the American Water Resources Association 36:919-930.

Manning, R. 1891. On the flow of water in open channels and pipes. Transactions of the Institution of Civil Engineers of Ireland 20:161-207.

Montegomery, D. R., AND S. M. Bolton. 2003. Hydrogeomorphic variability and river restoration. In: R. C. Wissmar and P. A. Bisson [EDS.]. Strategies for restoring river ecosystems: sources of variability and uncertainty in natural and managed systems. Bethesda, MD, USA: American Fisheries Society. p. 39-80.

Moran, M. S., R. D. Jackson, P. N. Hart, R. J. Slater, S. F. Bartell, F. Biggar, D. I. Gellman, and R. P. Santer. 1990. Obtaining surface reflectance factors from atmospheric and view angle corrected SPOT-1 HRV data. Remote Sensing of Environment 32:203-214.

Nagler, P. L., E. P. Glenn, and A. R. Huete. 2001. Assessment of spectral vegetation indices for riparian vegetation in the Colorado River delta, Mexico. Journal of Arid Environments 49:91-110.

PLumB, G. E., AND J. L. DodD. 1993. Foraging ecology of bison and cattle on a mixed grass prairie: implication for natural area management. Ecological Applications 3:631-643.

Porath, M. L., P. A. Momont, T. DelCurto, N. R. Rimbey, J. A. Tanaka, and M. Mclnnis. 2002. Off-stream water and trace mineral salt as management strategies for improved cattle distribution. Journal of Animal Science 80:346-356.

Sandercock, P. J., J. M. Hooke, and J. M. Mant. 2007. Vegetation in dryland river channels and its interaction with fluvial processes. Progress in Physical Geography 31:107-129.

SEDGWICK, J. A., AND F. L. KNopf. 1991. Prescribed grazing as a secondary impact in a western riparian floodplain. Journal of Range Management 44:369-373.

Sheffield, R. E., S. Mostaghimi, D. Vaughan, E. Collins, JR., and V. Allen. 1997. Offstream water sources for grazing cattle as a stream bank stabilization and water quality BMP. Transactions of the American Society of Agricultural Engineers 40:595-604.

Skinner, R. H., R. W. Zobel, M. van der Grinten, and W. Skaradek. 2009. Evaluation of native warm-season grass cultivars for riparian zones. Journal of Soil and Water Conservation 64:413-422.

Smart, A. J., B. H. Dunn, P. S. Johnson, L. Xu, and R. N. Gates. 2007. Using weather data to explain herbage yield on three Great Plains plant communities. Rangeland Ecology \& Management 60:146-153.

StubBendieCK, J. S., L. HATCH, AND C. H. Butterfield. 1992. North American range plants. 4th ed. Lincoln, NE, USA: University of Nebraska Press. $483 \mathrm{p}$.

SvoRAY, T. 2004. Integrating automatically processed SPOT HRV pan imagery in a DEM-based procedure for channel network extraction. International Journal of Remote Sensing 25:3541-3547.

Towne, E. G., D. C. Hartnett, and R. C. Cochran. 2005. Vegetation trends in tallgrass prairie from bison and cattle grazing. Ecological Applications 15:1550-1559. 
Vande Kamp, K. L. 2012. Implications of best management practices on channel evolution within the Bad River watershed: west central South Dakota [thesis] Brookings, SD, USA: South Dakota State University. 127 p.

Weaver, J. E. 1960. Flood plain vegetation of the central Missouri valley and contacts of woodland with prairie. Ecological Monographs 30:37-64.

WHITE, L. M. 1983. Seasonal changes in yield, digestibility, and crude protein of vegetative and floral tillers of two grasses. Journal of Range Management 36:402-405
Wuerthner, G. 1998. Are cows just domestic bison? Behavioral and habitat use differences between cattle and bison. In: L. R. Irby and J. E. Knight [EDS.]. International symposium on bison ecology and management in North America. Bozeman, MT, USA: Montana State University. p. 374-383.

Wylie, B. K., D. J. Meyer, L. L. Tieszen, and S. Mannel. 2002. Satellite mapping of surface biophysical parameters at the biome scale over the North American grasslands-a case study. Remote Sensing of Environment 79:266-278. 